Veterans Affairs (VA) Facilities. GA. Roselle, LH. Danko, SM. Kralovic, LA. Simbartl, KW. Kizer.

M70 Nosocomial Exposure to a Rapidly Replicating Strain of Mycobacterium tuberculosis. M. McCormick, G. Fuller, K Zink.

M71 Time to Negative AFB Smear and Culture in Patients with Active Pulmonary Tuberculosis. M. Nerkar, J. Briceno, R. Pepe.

M72 Comparative Time Study for Growth and Identification of Mycobacterium tuberculosis (MTB) versus Mycobacteria Other Than Tuberculosis (MOTT). JL Murillo, S. Ayyanathan, T. Chan.

M73 Tuberculin Skin Testing in Hemodialysis Units - 2 Year Follow-Up. KF. Woeltie, S. Seiler, VJ. Fraser.

M74 A Cluster of Tuberculosis (TB) Cases in a Renal Care Center. S. Simpkins, G. Bhatia, K Smith, C. Hench, L. Horn, ME. Russell, J. Lugovoy.

M75 Outbreak of Pulmonary Tuberculosis Among Laboratory Workers at a University Hospital, Peru, 1998. J. Alonso-Echanove, RM. Granich, NJ. Binkin, WR. Jarvis.

M76 Risk of Nosocomial Acquisition of Mycobacterium tuberculosis Infection Among Health Care Workers at a Brazilian Hospital. DO. Garret, V. Roth, K Laserson, FF. Almeida, B. Couto, CEF. Starling, N. Binkin, W. Jarvis.

M77 Evaluation of Tuberculosis Infection Among Healthcare Workers in a Teaching Hospital. RM. Almeida, MP. Verotti, SMTS. Rego Valdete, M. Ramos, CGJ. Marino, DJ. Haddad, D. Garrett, SB. Wey, EAS. Medeiros.

M78 Tuberculin Skin Test (TST) Positivity Rates Among Health Care Workers (HCWs) at a Brazilian Hospital. VR. Roth, DO. Garrett, E. Silva, AM. Lage, CEF. Starling, WR. Jarvis.

M79 Risk of Tuberculin Skin Test Conversion Among Employees at a Public Inner-City Hospital in a High Incidence Area. N. Larsen, MJ. Sotir, N. White, P. Parrott, NN. Bock, HM. Blumberg.

M80 Tuberculin Skin Test (TST) Conversion Rates Among Health Care Workers (HCW) in a Large Midwestern University Hospital. LB. Polish, SM. Seiler, VJ. Fraser.

\section{SURVEILLANCE, EPIDEMIOLOGY AND PREVENTION OF} SURGICAL SITE INFECTIONS

M81 A Two-Year Assessment of the Pathogen Frequency and Antimicrobial Resistance Patterns Among Organisms Isolated from Skin and Soft Tissue Infections in Latin American Hospitals: Results from the SENTRY Antimicm. AC. Gales, RN. Jones, HS. Sader, KA Gordon.

M82 A Department of Veterans Affairs (VA) Computerized National Surveillance System. GA. Roselle, SM. Kralovic, SE. Dane, LA. Simbartl, LH. Danko, KW. Kizer.

M83 Surveillance for nosocomial infections in a long-term care facility utilizing NNIS device-specific infection rates. KM. Ramsey, CF. Hoff, V. Danford.
M84 Electronic Tracking of Patients Harboring Resistant Bacteria in a Four-Hospital Health Care System (Inova). AJ. Morrison, G. Hansen, F. Vasaly.

M85 Fifteen Year Experience with Legionellosis at a Tertiary Referral Hospital. BR. Mooney, BG. Brintion, LJ. Eutropius, RL. Buxton, KC. Carroll, MH. Samore.

M87 Evaluation of Risk Factors Associated with Length of Stay, Complications and Death for In-Hospital Patients. R. Quiros, D. Espinosa, A. Torn, C. Romero, G. Del Barba, C. Espinoza, C. Rodriguez, A. Regueiro.

M88 Predisposing Factors Associated with Colonization or Infection with Stenotrophomonas maltophilia at a University Hospital. PD. Rogers, NJ. Dorman, JE. Humphries, JD. Cleary, RL. Nolan.

M89 Risk Factors for and Costs Associated with CeftazidimeResistance in Enterobacter cloacae. JM. Hyatt, S. Feuerstein, JJ. Schentag.

M90 Comparison of Physician Profiling through a Multi-factorial Model for Length of Stay Adjustment. R. Quiros, A. Torn, D. Espinosa, C. Romero, G. Del Barba, E. Avila, N. Cachaza, A. Pichonriviere.

M91 Control of Emerging Multiply Resistant Pseudomonas aeruginosa (MRPSA) in a Tertiary Care Teaching Hospital. L. Dowdy, S. Roger, V. Duquesne, B. Alfonso, J. Gonzalez, T. Cleary, O. Martinez.

M92 Improving Nosocomial Infection Rates: Institutional Interventions Needed for Success. C. Richards, R. Gaynes.

M93 Infection Control in 9 European Hospitals. DJMA. Beaujean, A. Troelstra, AJL. Weersink, J. Verhoef.

M94 Vancomycin Resistant Staphylococcus aureus (VRSA), Guilty until Proven Innocent. JF. Ober, MT. Wong, MB. Edmond.

M95 Quality Assessment trough Surveillance of Adverse Events in a Tertiary Referral Brazilian Hospital. FF. Almeida, MGS. Nogueira, SMC. Pinheiro, IHP. Neves, S. Mafra, BRM. Couto, CEF. Starling.

M96 Comparison between Three Simple Severity of Illness Indicators as Predictors of In-Hospital Death. R. Quiros, A. Torn, D. Espinosa, C. Romero, G. Del Barba, O. Morena, A. Quesada, S. Ruiz.

M97 Post Discharge Surveillance (PDS) Helps to Detect Urinary Tract Infections (USTI) in a Maternity in Ribeirao Preto, Brazil. SNS. Fonseca, MC. Menegucci, LA. Ferriani.

M98 Prospective Surveillance for Outbreaks of Respiratory Infection in Long-Term Care Facilities. M. Loeb, A. McGeer, M. McArthur, A. Simor.

M99 Inappropriate Antimicrobial Therapy as a Result of Overstated and Poorly Documented Penicillin Allergy. C. Lee, T. Zembower, M. Fotis, M. Postelnick, P. Greenberger, L. Peterson, G. Noskin.

\title{
Bacillus cereus Outbreak From Contaminated Ventilator Circuits
}

\section{Gina Pugliese, RN, MS Martin S. Favero, PhD}

An outbreak of Bacillus cereus respiratory tract infections affecting six ventilated preterm neonates over a 2-week period was reported by Gray and colleagues. Reusable ventilator circuits were identified as the cause of the outbreak. Ordinarily these were reprocessed on the neonatal unit (NNU), first through a washing machine and then through a low- temperature steam (LTS) disinfector. The onset of the outbreak coincided with a breakdown of the LTS facility, which necessitated sending the washed circuits off-site for LTS disinfection. The washing machine was shown to be contaminated with the same serovars of $B$ cereus as those isolated from patients. Two critical steps in the off-site LTS disinfection process allowed exsporulation and multiplication of $B$ cereus: the circuits were dried inadequately after processing, and return of the moist circuits to the NNU often was delayed. The outbreak was terminated by withdrawal of the heatdisinfected ventilator circuits. This outbreak emphasizes the need for high standards where medical equipment is reprocessed, especially for use in vulnerable patients.

FROM: Gray J, George R, Durbin GA, Ewer $\mathrm{K}$, Hocking D, Morgan M. An outbreak of Bacillus cereus respiratory tract infections on a neonatal unit due to contaminated ventilator circuits. $J$ Hosp Infect 1999;41:19-22. 

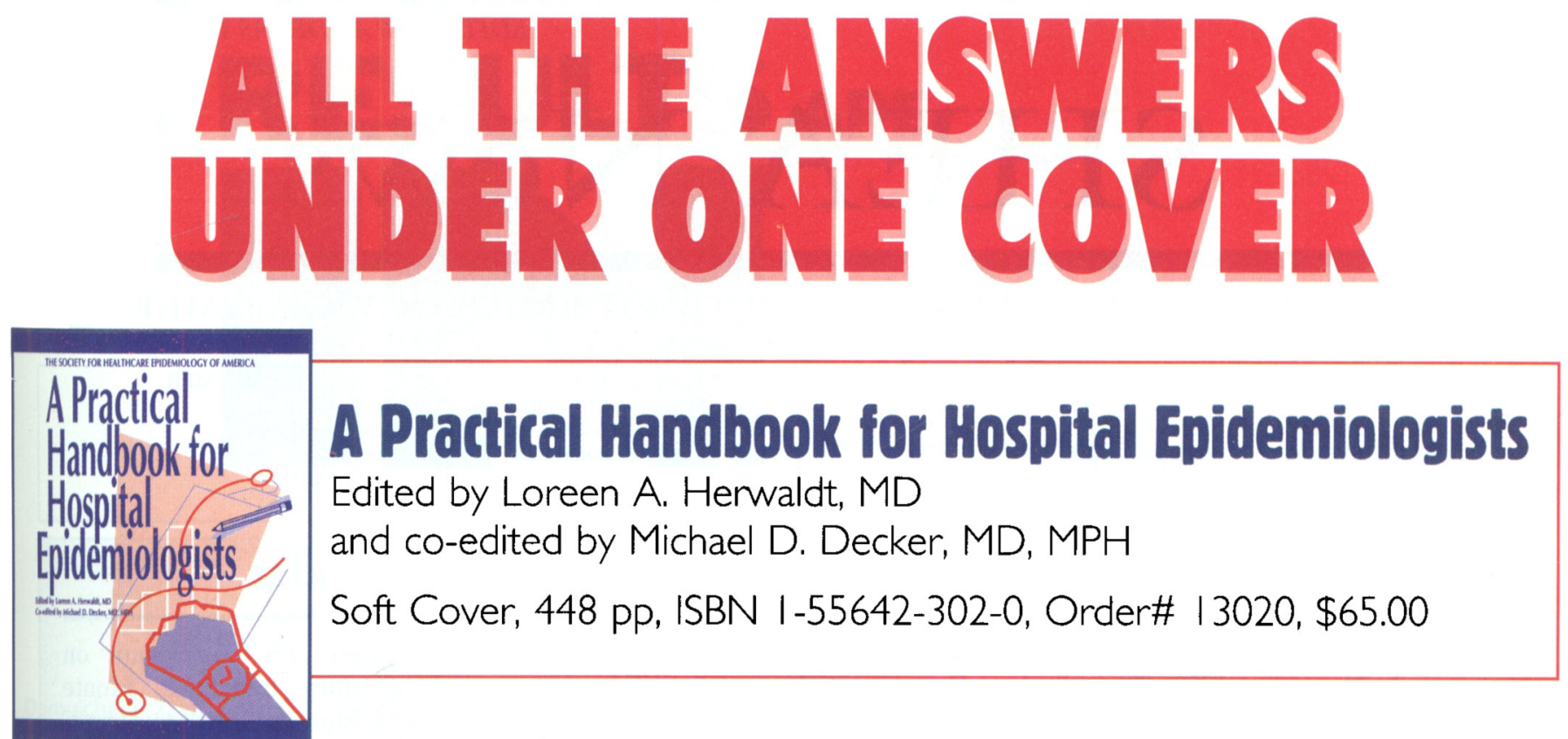

A Practical Handbook for Hospital Epidemiologists is the most complete source for practical advice on hospital epidemiology. It is intended to be a pragmatic guide that will assist both beginning and experienced epidemiologists in establishing and operating a successful hospital epidemiology program.

This handbook will supplement the various scientific references already available for hospital epidemiologists. It will provide practical information and advice regarding many aspects of operating a hospital epidemiology program and will help hospital epidemiologists improve their practices.

The Society for Healthcare Epidemiology of America (SHEA) has recruited the most recognized leaders in

\section{Contents}

\section{Getting Started}

Chapter I: An Introduction to Practical Hospital Epidemiology

Chapter 2: The Hospital Epidemiologist Practical ideas

Chapter 3: Educational Needs and Opportunities for the Hospital Epidemiologist

Chapter 4: Negotiating with the Administrationor How to Get Paid for Doing Hospital Epidemiology

Chapter 5: The Infection Control Committee

Chapter 6: Developing Policies and Guidelines

Chapter 7: intramural and Extramural Communication

Chapter 8: Ethical Aspects of Infection Control

Surveillance and Analysis

Chapter 9: Basics of Surveillance-An Overview

Chapter 10. Hospital-Acquired Pneumonia:

Perspectives for the Healthcare Epidemiologist

Chapter I 1: Basics of Surgical Site Infection Surveillance

Chapter 12: Surveillance for Infections Associated with Vascular Catheters

Chapter 13: Designing Surveillance for Noninfectious Outcomes of Medical Care

Chapter 14: Outbreak Investigations

Chapter 15: Exposure Workups

Chapter 16: Isolation

Chapter 17: Basics of Stratiffing for Severity of Illness

Chapter 18: Quantitative Epidemiology
Support Functions

Chapter 19: Microcomputers in Hospital Epidemiology

Chapter 20: The Computer-Based Patient Recond: The Role of the Hospital Epidemiologist

Chapter 21: Basic Microbiologic Support for Hospital Epidemiology

Chapter 22: Epidemiologic Typing Systems

Special Topics

Chapter 23: Epidemiologic Approaches to Quality Assessment

Chapter 24: Disinfection and Sterilization of Patient Care Items

Chapter 25: Controlling Use of Antimicrobial Agents

Chapter 26: Employee Health and Infection Control

Chapter 27: Tuberculosis Control in Healthcare

Chapter 28: Infection Control Issues in Construction and Renovation

Chapter 29: Hospital Epidemiology in Smaller Hospitals

Chapter 30: Infection Control in Public Hospitals

Chapter 31: Infection Control in Long-Term Care Facilities

Chapter 32: Infection Control in the Outpatient Setting

Chapter 33: OSHA Inspections

Chapter 34: Preparing for and Surviving a JCAHO Inspection

Chapter 35: Product Evaluation the field to share their expertise. They will share successful strategies for handling specific situations. The authors cover many topics that every newcomer should know but are usually learned through experience. These topics include:

- Overarching goals and ethical principles you should adopt to guide your practice

- What you can do to educate yourself

- How to negotiate with the administration and communicate with colleagues

- How to develop policies and procedures

- How to develop a surveillance system

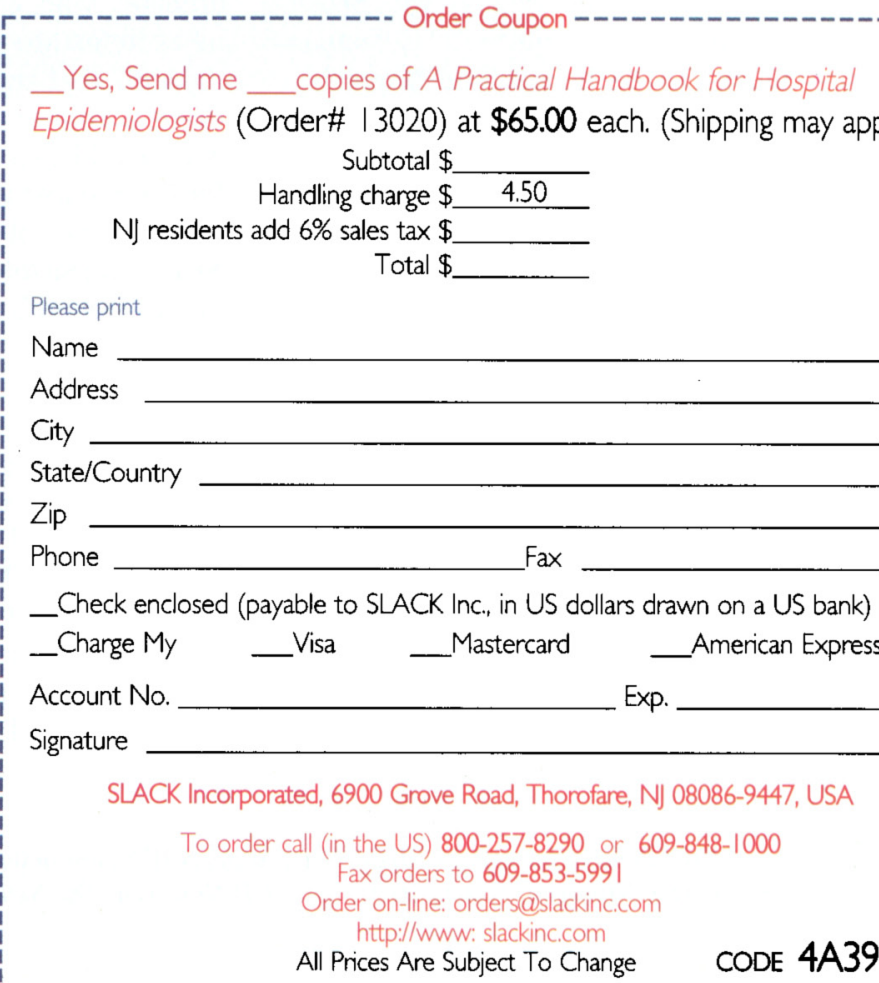

